\title{
MARIA NAVALHA E A FILOSOFIA POPULAR BRASILEIRA - UM “TRABALHO” DE CAMPO
}

\author{
Rafael Haddock-Lobo ${ }^{1}$ \\ DOI 10.26512/revistacalundu.v4i2.34990
}

\begin{abstract}
Resumo
O objetivo deste trabalho consiste em demonstrar como certos conceitos são desenvolvidos a partir da perspectiva de uma filosofia popular brasileira. Para além de apenas explicitar teoricamente os passos fundamentais para a elaboração conceitual (quais sejam, o trabalho de campo ou o "trabalho" da e na rua, as anotações que se seguem à experiência, a escrita a partir de tais anotações, tendo o conceito apenas como resultado final e não o norteador da escrita), esse texto parte de um caso específico, ao qual se seguiram algumas outras experiências, para, nos termos de Luiz Rufino, alcançar uma "pedagogia das encruzilhadas". É apenas a partir das experiências, anotações e posterior escrita, em que a cada etapa a figura de Maria Navalha, pombagira malandra carioca, vai se tornado mais presente, que os conceitos de "exubjetividade", "dona da navalha", "navalha de gênero" e "filosofia a golpes de navalha" vão tomando forma. Ainda assim, é preciso observar, mais do que conceitos fechados, esses termos entram na gira para desconceituar, a golpes de navalha, tudo aquilo que se pretende uno, coeso, perene e idêntico a si.
\end{abstract}

Palavras-chave: Experiência. Trabalho de campo. Filosofia Popular Brasileira. Navalha. Exubjetividade. Desconceito.

\section{MARIA NAVALHA Y LA FILOSOFÍA POPULAR BRASILEÑA - UN “TRABAJO” DE CAMPO}

\section{Resumen}

El objetivo de este trabajo es demostrar cómo se desarrollan ciertos conceptos a partir de la perspectiva de una filosofía popular brasileña. Además de explicar teóricamente los pasos fundamentales para la elaboración conceptual (es decir, el trabajo de campo o el "trabajo" de y en la calle, las notas que siguen a la experiencia, la escritura a partir de esas notas, teniendo el concepto solo como resultado final y no como principio rector de la escritura), este texto parte de un caso concreto, seguido de algunas otras experiencias, con el propósito de, según Luiz Rufino, llegar a una pedagogía de la encrucijada. Es solo a partir de vivencias, apuntes y escritos posteriores (y en cada etapa se hará más presente la figura de María Navalha, pombagira malandra carioca), que los conceptos de "exubjetividad", "dueña de la navaja", "navaja de género" y la "filosofía de golpes de navaja” irán tomando forma. Aun así, es necesario observar que, más que conceptos

\footnotetext{
1 Doutor em Filosofia pela PUC-Rio e pós-doutorado na Faculdade de Filosofia, Letras e Ciências Humanas da USP (com bolsa da FAPESP), no Instituto de Estudos da Linguagem da UNICAMP (com bolsa do CNPq) e no Instituto de Filosofia e Ciências Humanas da UERJ. É professor do Departamento de Filosofia e dos Programas de Pós-Graduação em Filosofia da UFRJ e da UERJ. Email: outramente@yahoo.com
} 
cerrados, estos términos entran en la "gira" para desconceptualizar, con golpes de navaja, todo lo que se pretende como uno, cohesionado, perenne y auto-idéntico.

Palabras clave: Experiencia. Trabajo de campo. Filosofía Popular Brasileña. Navaja. Exubjetividad. Desconcepto.

Para Katia Barbosa e Dona Maria Navalha da Lapa

\section{Abertura - A navalha na carne negra}

Neusa Sueli: - Vovó das putas é a vaca que te pariu.

(Plínio Marcos, Navalha na Carne)

Pouco mais de cinquenta anos depois, a peça de Plínio Marcos era encenada sob uma nova pegada, sob a direção de José Fernando Peixoto de Azevedo. A puta, o cafetão e a bixa ${ }^{2}$ são, eles próprios, as navalhas e a pele negra navalhada, como se a peça cinquentenária fosse reescrita por esses corpos que ecoam n'A carne as letras de Yuka e a voz de Donas Elzas e Seus Jorges.

Todos pretos, atriz, atores e diretor ${ }^{3}$, rasuram a branquitude dos palcos e dos textos com suas navalhas, mostrando suas peles, costumadas a ser enviadas de graça pro presídio, pros hospitais psiquiátricos, pros subempregos e pra debaixo do plástico ${ }^{4}$. Agora, contudo, em um movimento de inversão e deslocamento ${ }^{5}$, as peles negras entram em cena para não apenas denunciar o epistemicídio e a necropolítica, mas para serem ostentadas, esfregando sua vitalidade na cara da branquitude, sambando na tumba de uma civilidade morta, em sua falsidade, hipocrisia e ressentimento. José Fernando Peixoto de Azevedo, o diretor desse manifesto, invocando Lucelia Sergio, Raphael Garcia, Rodrigo dos Santos, navalha a própria carne de Plínio Marcos - mas não para destruí-lo.

Ao contrário, a encenação navalhada de Navalha na Carne Negra é posta em cena justamente para fazer justiça ao que há de mais navalhado na peça original, o jogo

\footnotetext{
${ }^{2}$ A grafia remete ao termo de Paco Vidarte, em Ética bixa (n-1, 2018).

3 A peça, em cartaz em 2018, tem direção de José Fernando Peixoto de Azevedo, com os atores Lucelia Sergio, Raphael Garcia, Rodrigo dos Santos.

${ }^{4}$ Referências à música "A carne", de Ulisses Cappelletti, Jorge Mario Da Silva e Marcelo Yuka, gravada no álbum "Moro no Brasil" (de 1998) do grupo Farofa Carioca e depois eternizado na voz de Elza Soares no álbum "Do cóccix até o pescoço" (de 2002).

${ }^{5}$ Os termos são utilizados pelo filósofo argelino Jacques Derrida para explicitar o que seria a arquitetura estratégica da “desconstrução" (DERRIDA, 2001, 48-49).
} 
entre o cafetão, a bixa e a puta que, quando representados como e por pessoas brancas, nunca alcançarão a realidade potente e viva das ruas.

Navalha na carne negra é a dupla navalha, a navalha sobre a navalha, a navalha na carne mas também da carne negra, o duplo jogo que, como ensina Maria Navalha, consiste em ser ao mesmo tempo a vara curta que cutuca a onça e a onça que é cutucada.

Quando falo em alcançar a realidade potente e viva das ruas, ou seja, tentar fazer justiça ao que está aí, diante de nós. Quero dizer com isso, e por isso esta encenação que remete a outra e a chama para perto do mundo é paradigmática, que a melhor maneira de representar as ruas é partir de alguma experiência - nunca do universal para o particular.

Também, é bom lembrar, que tão pouco parece um movimento que se dirige de uma experiência singular que deve ser universalizada. A representação das ruas, para ecoar as ruas, deve propor um jogo de espelhamento entre as singularidades, resistindo ao máximo à colonização do universal, que pretende justamente abstrair toda singularidade. Para falar e escrever sobre as ruas (não de sua alma encantadora, como queria João do Rio (RIO, 2012), mas de seu corpo encantado (SIMAS, 2019), como propõe Luiz Antonio Simas), é preciso, como fizeram esses dois grandes pensadores rueiros, ir para às ruas.

Ir às ruas quer dizer simplesmente: ir ao encontro do que não se espera, estar disponível a ser surpreendido, estar aberto à experimentação. Se encontramos o que esperávamos, nem vale a pena perder tempo na escrita, pois nenhuma experiência foi realmente vivenciada e, nesse sentido, tanto faz estar em casa ou nas ruas. O que é digno de nota - e sublinho, seguindo os rabiscos de Walter Benjamin e Guimarães Rosa - é aquilo que acontece para além de toda expectativa e que, por isso, precisa ser anotado.

Benjamin e Rosa nos ensinam que o filósofo das ruas, que é o filósofo nas ruas, precisa ter consigo sempre seu caderninho de notas, para não deixar escapar - sabendo que sempre vai escapar - o que lhe surpreende. Notas e notas, rabiscos e rabiscos, memórias do dia seguinte, letras trêmulas da bebedeira ou nubladas de ressaca são, ou deveriam ser, matéria privilegiada para o filósofo. É a partir disso, do que se viveu, do que se bebeu e se comeu, dos cheiros, dos temperos, dos suores, das salivas, dos sons e das letras, de todas essas palavras encantadas que tentamos captar, que o filósofo precisa partir para a experiência de pensamento. 
Uma filosofia que possa ser considerada verdadeiramente brasileira e popular deve partir da própria experimentação, com seu próprio sotaque, e afirmar a regionalidade contra a universalidade. Não para uma exaltação de si em detrimento do outro, mas, ao contrário, como uma presentação de si que na verdade é um convite para que outras vozes, outros sotaques, outras experiências também entrem em cena.

É nesse sentido que quando proponho, eu, fazer uma filosofia popular brasileira, só posso fazer isso a partir de meu lugar como carioca, homem branco, bicha, com sobrenome de colonizador, crescido em um bairro de classe média do Rio de Janeiro (que pretende apagar seus rastros populares das ruas, dos bares e dos morros), tendo o privilégio de a macumba cair sobre a minha cabeça desde cedo em minha vida. Só a partir daí, disso que vivo e que me constitui, posso empreender uma filosofia que, como diria Nietzsche, seja feita com sangue, mas, como ensina Maria Navalha, com o sangue meu e do outro, o sangue que é também o das batalhas, das lutas, dos inimigos. É com esse sangue que, com a ponta da navalha, gostaria um dia de ter a força para escrever.

Nesse sentido, esse texto aqui nada mais é que um experimento. Ou melhor, um relato sobre as anotações que se seguem a algumas experiências que se impuseram a mim, ou melhor, me aconteceram. Ele não propõe nada de original, nenhuma novidade, é uma reflexão - um espelhamento - de situações, a partir de situações, e que me levaram a outras situações. Poderia ser considerado uma espécie de relatório filosófico de um trabalho de campo mas que, talvez, seja mais justo chamar de um trabalho nas ruas.

Só espero conseguir corresponder aos chamados, às graças e alegrias, às surpresas, às amizades, às proteções, em especial das moças que andam pelas ruas, vivas ou mortas, encantadas, com suas lâminas por debaixo das roupas, com tanto a ensinar, querendo ensinar, me obrigando a aprender. Saravá!

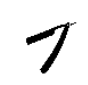

\section{Primeiro golpe: A anunciação}

Traz um sorriso no rosto e uma arma na saia O seu nome é, é Maria Navalha (Ponto de Maria Navalha) 
Era uma sexta-feira, por volta das 13 horas. 16 de agosto, 2019. Eu e minha amiga Elisa de Magalhães aguardávamos o início de nossa disciplina de pós-graduação para alunos da filosofia e das artes visuais que aconteceria no Centro Municipal de Arte Hélio Oiticica. Conversávamos distraidamente, quando entra na sala uma pessoa jovem, cujo corpo dificilmente deixa ver quaisquer marcas de gênero, enquanto a marca social se faz ver imediatamente pela pele negra, pelas cicatrizes no corpo e pela aparente embriaguez ou qualquer outro estado de entorpecimento. Se anunciou: Sou Maria navalha. Usava uma saia que só deixava transparecer os pés sujos e descalços. "Estou aqui a mando de Sete Encruzilhadas", continuou, exibindo orgulhosamente uma tatuagem no braço que parecia um ponto riscado, com tridentes cruzados e outros traços que, de minha distância, eram indiscerníveis.

Uma coisa era certa, aquela figura fluida, para além do masculino e do feminino, ao exibir seu braço tatuado ganhava ainda mais minha atenção, pois se dizia porta voz daquele que me acompanha, me cuida e abre meus caminhos. Disse que queria dinheiro. Que precisava comprar cerveja, tirando seu chapéu panamá e jogando ao centro da roda de conversas que ainda não tinha se completado. O chapéu flutuou, bailando como o élitro que flutua, pairando exatamente no centro de todos nós, professores e alunos. Como se aquele lance fosse alguma arte de extrema técnica ou de absoluta magia.

Pedi a todos e todas que ajudassem na cerveja de Maria Navalha, pois me pareceu mais que merecido. Ela se sentou. Começamos nossa primeira aula, eu e Elisa, depois de saudarmos Exu e, mais precisamente, essa mensageira, que chegava não sei porque e não sei de onde. Quando a aula de fato se adianta, ela se levanta, sem interesse algum no que falávamos, e vai, para onde ou de onde só ela sabe.

Terminando a aula, tinha que correr para o Instituto de Filosofia e Ciências Sociais, que fica bem perto, para dar início o curso de graduação, às 17 horas, que começaria com uma pequena homenagem aos 15 anos de morte do filósofo francoargelino Jacques Derrida. Além de dar início à disciplina de graduação, a mesa, composta por Fabio Borges-Rosário e Marcelo José Derzi Moraes, foi também a inauguração do Seminário Encruzilhadas, cujos textos se encontram publicados no livro Encruzilhadas filosóficas, e o batismo do laboratório coordenado por mim (que, antes chamado Laboratório Khôra de filosofias da alteridade, passa a se chamar Laboratório $\mathrm{X}$ de Encruzilhadas Filosóficas).

Quando meus convidados chegaram, comecei a contar aos dois a inóspita cena que antecedeu minha aula da graduação, quando Fábio Borges-Rosário me interrompe e 
pede para eu parar de contar e que eu entenderia a razão logo em seguida. Não entendi e nem dei muita atenção no momento. Chamei os dois, que se sentaram junto à bancada do lindo auditório de madeira, a sala em que dou aulas todas às sextas feiras às 17 horas, quando Fábio Borges começa a ler seu texto sobre uma (im)possível e (im)provável vinda de Derrida ao Brasil.

Com licença das encruzilhadas: Saúdo a Exu Rei das Sete Encruzilhadas, Exu Tranca Ruas das Almas, Exu Mirim, Exu Gira Mundo, Dona Cruzeiro, etc. Dona Jocília Borges, Dona Maria Barcelos, Dona Iara Joio; etc. Isto é, a todas e todos que estão espectralmente presentes para nos acolher e garantir acontecimentos de resistência aos fantasmas que tentam obsidiar a Filosofia amordaçando-a nas margens e fronteiras da Europa. (Borges-Rosário, 2020, pág. 29)

Inaugurava-se, naquele momento, uma forma de escrita corajosa, ousada e que marcaria profundamente a todos nós ali presentes. Fabio trazia as encruzilhadas para a desconstrução, ou melhor, mostrava as encruzilhadas da desconstrução e o quão potente seria esse encontro entre Derrida e macumba.

Lembrando que Derrida falecera logo após uma viagem ao Brasil (onde deu sua última conferência), Fabio desfia seu Rosário apresentando os temas da espectralidade, o nome que a desconstrução dá para ancestralidade, das margens, nome derridiano das encruzilhadas, e de como o filósofo magrebino, a partir de então, se tornaria mais um de nossos ancestrais - iniciando assim seu "ai se sesse...":

E enquanto os espectros que retornam para obsidiar enclausuram-se nas casas, bibliotecas, faculdades, departamentos para garantir a repetição da mesmidade e impedir a novidade, quiçá o filósofo da iterabilidade tenha preferido atravessar o oceano e vir às terras brasileiras para conhecer outras mitologias com os ancestrais que habitam as ruas, matas, cachoeiras, terreiros. (Borges-Rosário, 2020, pág. XX)

Essa fala de Borges-Rosário marcaria o cruzo ${ }^{6}$ entre desconstrução e macumba, entre realidade e ficção, atacando o centro da filosofia em um duplo golpe. E para a surpresa de todas presentes, quem aparece para receber o Derrida-ancestralizado em nossas terras?

\footnotetext{
${ }^{6}$ Sobre isso, remeto ao capítulo "Cadê Viramundo, pemba?" de Fogo no mato: a ciência encantada das macumbas, que apresenta o cruzo como "perspectiva teórico-metodológica assentada nos complexos de saber das macumbas brasileiras" (SIMAS e RUFINO, 2018, 25).
} 
Um dia... Quando chegou ao Porto da cidade do Rio de Janeiro Derrida avistou um malandro vestido de saia. Lembrou da malandragem parisiense, lembrou de Jean Genet. Talvez, pensou que aquela pessoa era não binária ou transgênero. Percebendo o embaraço do argelino, Maria Navalha se aproximou e lhe deu um endereço. Infelizmente como Derrida só fala uma língua que não lhe pertence e Maria Navalha só escreve em pretuguês, não entendeu o endereço. Pensou na ginga daquela mulher. Avistou uma menina trajada como mulher; outra que se portava como rainha; outra ainda que num raro momento de ócio, lembrou dos filhos que deixara chorando. Pensou novamente em Genet e decidiu seguir até que encontrasse a mulher que procurava. (Borges-Rosário, 2020, pág. XX)

De tal modo surpreso pela dupla chegada dessa moça em um mesmo dia, parecia não conseguir acompanhar a linda mesa que se seguia, as belas falas de Fabio e Marcelo, o debate que encerrou o evento. Quem é essa mulher? Porque apareceu? O que ela abre? Fabio, um filósofo que encruza Exu e Lutero e que entende bem desses encantos, também estava impactado pela co-incidência de Navalha. Só sabíamos, eu e os dois desenroladores, naquele momento que, de algum modo, por alguma razão, ela veio.

Fomos todos a irmos ao BDP, o bar que, em minha época de graduação era chamado de Bar das Putas (porque, de fato, ali, na Praça Tiradentes, era o local onde as trabalhadoras ficavam), mas que depois da "recuperação" (isto é, higienização) da região do Centro do Rio, passou a se chamar Bar da Praça (sic). Sentamos, pedimos uma cerveja. E o primeiro gole foi dela.

Passei dias, meses, e confesso que ainda estou tentando - aqui, justamente nesse texto - entender o alcance da entrada em cena dessa malandra, abrindo o semestre, inaugurando o seminário, batizando meu laboratório e nos convocando a outras escritas filosóficas. Dela, até então, só sabia que gostava de cerveja, que trazia "um sorriso no rosto e uma arma na saia”. E seu nome, saravá, Dona Navalha!

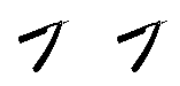

\section{Segundo golpe: discurso do método se faz é no bar}

O Zé quando vem de Alagoas, toma cuidado com o balanço da Canoa. 
(Ponto de Zé Pelintra)

Ao longo do semestre, comecei a rascunhar um texto inspirado na capa do livro Coreografias do feminino, de minha amiga Carla Rodrigues, que, para mim, antevê muito dos percursos que sua escrita tomaria para além daquele momento, através da linda imagem de um corpo negro, de mulher, de rosto não visível e vestimenta esvoaçante. A ideia do texto era, a princípio, passear pela figura do Esù, o orixá africano, portador do Ogó, passando pela bengala de Tranca Rua, feita de madeira que não dá cupim, até chegar à noção de padilhamento $^{7}$, cunhada por Simas e Rufino em Fogo no mato, para pensar a questão do feminino que via estampada na capa do livro de Carla.

Quando fui convidado por Marco Antônio Casanova para participar em novembro de uma mesa sobre gênero no XII Congresso Internacional "Questões fundamentais da hermenêutica filosófica": identidades, resistências e gêneros, já me lancei então o desafio: falaria, então, sobre os gêneros das ruas, flutuando entre o masculino e o feminino, de Esù aos exus e pombagiras da umbanda carioca ${ }^{8}$. Contudo, como sempre acontece quando o método não é o cartesiano (que parece saber onde vai chegar antes mesmo de ir), mas o riobaldiano (em que se atravessa o rio a nado querendo chegar numa banda, mas se chega num lugar bem diverso do que antes se pensou), muitas coisas aconteceram ao longo dessa escrita. Aliás, não muitas coisas, mas muitas pessoas - a malandragem se impôs. Três figuras foram chegando para tocar o zaralho no meu texto e desconceituar minhas concepções: um José, um João e uma Maria.

Era dia 5 de novembro de 2019, no Bar Madrid. O bar, no bairro da Tijuca, estranhamente lotado em uma terça-feira à tarde, aguardava a fala de Luiz Antonio Simas. A promessa: falar das pelintrações. A fala, magnânima, traçava os contracaminhos, aparentemente opostos, de Zé Pelintra e Luiz Gonzaga. O primeiro, catimbozeiro pernambucano, morador da rua da Amargura, troca suas roupas de

\footnotetext{
7 Sobre isso, remeto ao capítulo "Quem tem medo da pombagira??" de Fogo no mato: a ciência encantada das macumbas, onde se lê o seguinte: "Torna-se emergencial rodas as saias a fim de incorporar movimentos que credibilizem outros conhecimentos. Nessa encruza, a pombagira baixa para destravar os nós do corpo e praticar um giro enunciativo que opere a favor do combate às injustiças cognitivas, sociais e da disciplinarização dos corpos. (...) Os giros das saias rodadas nos indicam outras rotas, chamaremos uma dessas perspectivas transgressivas de padilhamento dos corpos" (SIMAS e RUFINO, 2018, 96).

${ }^{8}$ Como disse na apresentação do texto, só posso falar das experiências que me constituem, por isso a ênfase nas macumbas cariocas. Minha filosofia popular brasileira tem sotaque carioca, fala desses encontros que tive e tenho, mas precisa permanecer sempre aberta para outros encontros por vir.
} 
juremeiro pelo traje do malandro carioca ao chegar por essas bandas daqui; o segundo, também pernambucano, nascido em Exu, ganha suas vestimentas emblemáticas de "nordestino" quando sai de sua terra. Segundo Simas, o que os dois teriam em comum seria a pelintração, que nada tem a ver com resignação, mas sim com uma forma de adaptação transgressora. Mais recentemente, o malandro Simas lançou em sua conta de twitter um macumbaforismo de Seu Camisa Preta que traduz melhor do que qualquer conceitualização o que é pelintração: "Malandro usa sapato para continuar andando descalço".

Era isso de que precisava. Se há alguma metodologia possível para se falar das ruas, esse método tem de ser a própria pelintração, aprender com o cuidado que o malandro tem com o balanço da canoa, saber que na hora que a polícia chega, quem é malandro não pode correr e que, se a academia é a grande sapataria do pensamento, precisamos botar nossos sapatos bicolores para poder escrevermos descalços.

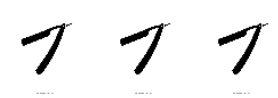

\title{
Terceiro golpe: Navalhada no gênero
}

\author{
Vocês estão vendo aquela casa pequenina, \\ lá no alto da colina, ele mandou fazer. \\ É lá que malandro mora, otário não tem moradia. \\ (Ponto de Malandro)
}

Dia 6 de novembro de 2019. Quarta-feira. O auditório da UERJ estava relativamente cheio para a mesa de abertura, da qual eu faria parte. Minha fala, "Os gêneros das ruas: notas de filosofia popular brasileira" ${ }^{10}$ tinha tomado um rumo bem diverso do que eu antes pensava. O que aconteceu nesse percurso que eu antes pensara, que partia do ogó e chegava à saia, passando pela bengala, é que a ginga da malandragem era necessária para operar a transição dos gêneros, e o objeto de corte dessa operação é justamente a navalha.

\footnotetext{
${ }^{9}$ Publicação de 22 de outubro da conta do Twitter de Luiz Antonio Simas.

10 A fala, apresentada primeiramente no XII Congresso Internacional "Questões fundamentais da hermenêutica filosófica": identidades, resistências e gêneros, na UERJ, em 6 de novembro de 2019, foi publicada pela primeira vez em 4 de dezembro de 2019 na minha coluna "Filosofia Popular Brasileira", na HH Maganize (https://hhmagazine.com.br/os-generos-das-ruas/) e depois inserida no capítulo "Ensaios de Filosofia Popular Brasileira" de meu Os fantasmas da colônia (HADDOCK-LOBO, 2020).
} 
Depois do discurso do método de Simas, cheguei em casa para terminar meu texto e percebi que entre José e Maria havia um João. Olha só, logo ele que me acompanha há anos, cuja biografia li ainda menino entre os livros do meu pai, cujo túmulo visito quando vou a Ilha Grande, que já li, estudei e até dediquei um texto: João Francisco dos Santos ou Madame Satã. A bicha preta quizumbeira, que enfrenta qualquer macho com seu soco de caranguejo, como contam Marcelo Moraes e Adriano Negris, só tem como peso no bolso a navalha ${ }^{11}$. Qual o poder dessa navalha nas mãos da bicha que é malandro, que é mulata do balacochê, que é Jamacy? O caminho entre o Bar Madrid e a minha casa (que não é nada longo) foi marcado pela ideia doida de não saber como João Francisco baixaria num terreiro, malandro ou pombagira? ${ }^{12}$

Esse malandro dia-bólico me lembrou da entrada triunfante em minha sala de aula no começo do semestre: aquele corpo que poderia ser de menino ou menina, indistinto, e que só fazia ver que a distinção não importava nada, mas que portava seu chapéu de malandro e sua saia, com seu corpo riscado a golpes de navalha. Sim, não apenas a navalha, o objeto, como Navalha, a moça, reaparecia para me convocar a escrever.

Depois da episteme pelíntrica, Zé parece ter me mostrado João, que, como não é bobo, já trouxe Maria junto. Madame Satã me mostrava que entre o malandro e a malandra a distância é apenas o fio de uma navalha, e que a navalhada é operação de profunda transição: só há pelintração, só há adaptação transgressora se, no bolso ou por debaixo da saia, houver uma navalha bem guardada e pronta a ser usada a qualquer momento.

João, Maria e José, ou Satã, Navalha e Pelintra, me rodearam noite adentro, transicionaram meu texto e me acompanharam até o auditório da universidade, me dando de presente uma navalha, mais potente que o martelo de Nietzsche, que suas

\footnotetext{
${ }^{11}$ Marcelo José Derzi Moraes e Adriano Negris, em seu potente texto "Escrituras da cidade: ordem e desordem a partir de Derrida", nos dizem: "O único peso é a navalha que carrega no bolso e a única leveza é a da mão que entra nos bolsos alheios e traz o alimento do dia. (...) Um analfabeto que escreve. Um marginal que é madame. Uma madame que é satânica. Um gay viril. Madame Satã não era nem seu nome. Seu nome era: João Francisco dos Santos. Três nomes que fazem referência ao religioso, ao sagrado. Nomes de santo num corpo de satã. Uma Madame Satã dos Santos. Um pecador com nome de santo. Salve todos os santos, salve Madame Satã, hoje padroeiro da Lapa" (SOLIS e MORAES, 2016, 56$64)$.

${ }^{12}$ Essa ideia que me tomou na volta do bar acabou cumprindo parte fundamental no já citado "Os gêneros das ruas", mas também reaparece como golpe importante no capítulo "Quizumba", do Arruaças, como "Madame Satã e a rasteira em Espinosa" (SIMAS, RUFINO e HADDOCK-LOBO, 2020, 80-84), ressaltando a estratégia de combate corporal e de ginga desconceitual que a filosofia popular brasileira ensina.
} 
esporas segundo Derrida, que as tesouras desse, segundo Preciado, que marca na carne ou na cara dos otários o próprio pensamento.

\title{
フフフフ
}

\section{Quarto golpe: De cara com a Navalha}

\author{
Mulher de malandro tem nome e se conhece pela saia \\ Vara curta e onça brava, ela é Maria Navalha. \\ (Ponto de Maria Navalha)
}

Era a semana antes do carnaval. Sábado, 15 de fevereiro de 2020. Acabava de completar 45 anos e ia festejar na gira de exu para firmeza do carnaval. Embora não fosse nem pisar na rua ao longo das próximas semanas, com um livro a terminar, não ia deixar de visitar meus amigos na rua Castro Lopes 310 no bairro de Inhaúma, subúrbio carioca.

Sabia que encontraria meus amigos Exu Tiriri, Seu Zé Pelintra, que é quem faz a festa na casa, Seu Sete Caveirinhas, minhas amigas Dona Figueira, Pombagira do Lodo e Maria Padilha. O que eu não esperava é que Dona Padilha ficaria pouco tempo na terra porque Maria Navalha queria me ver.

Arrepiei.

Todo prosa, e esquecendo que a língua da macumba é a do segredo, pensei: tudo resolvido. Agora ela vai me contar tudo. Por que apareceu para mim, qual a razão de ela estar na minha vida tão intensamente nos últimos tempos, tudo, tudinho.

Para quem queria resposta, dei de cara na porta. Olha aí a verdadeira aporia.

Linda, mais dura que Padilha e menos bruta que Mulambo, ela veio até mim com seu pito na mão e uma cerveja na outra: "Oi moxo, queria dá um abraxo no sinhô". Ganhei meu abraço, agradeci muito e quis saber do tudo que ela tinha para me contar. Sorriu, disse que trabalhava com Seu Sete Encruzilhadas, meu exu, que se chamava Maria navalha da Lapa e me mandou botar uma navalha na porta da minha sala onde trabalho (no Instituto de Filosofia e Ciências Sociais da UFRJ). Se despediu, me deu outro abraço, e foi oló. 
Numa estrada tão bonita, numa noite de luar Numa estrada tão bonita, numa noite de luar. (Ponto de subida de exu)

Fomos passeando, cada um em sua estrada bonita, na linda noite de luar: ela, não sei para onde e vi que não saber era minha tarefa; eu, para casa, pensando muito, entendendo nada, mas com a certeza de que, de fato, com a navalha na porta de minha sala, a Maria que porta o nome do objeto cortante e que o guarda sob sua saia era não só a madrinha do Laboratório X de Encruzilhadas Filosóficas como a guardiã daquele espaço. Mas essa certeza era acompanhada de outra certeza ainda maior: que ainda tinha muita coisa por vir.

Ainda no caminho para casa, encomendava ansioso a navalha que me tinha sido pedida, e aproveitei e achei uma linda imagem de gesso, de 20 centímetros, que encomendei e pedi urgência na entrega, pois a escrita que tinha à frente seria feita à luz (de vela) de Dona Maria Navalha.

\section{フフフフフ}

\section{Quinto golpe: Arruaças carnavalescas}

Ela é mulher, ela é bonita e formosa mas não se engane, ela é muito perigosa. (Ponto de Maria Navalha)

Era carnaval e nem imaginávamos que seriam as últimas semanas de respiro prépandêmico. Minha navalha e a imagem da dona do objeto haviam chegado. Grande parte dos textos que preparava para o Arruaças, livro que escrevia com Luiz Antonio Simas e Luiz Rufino estavam ainda em forma de anotações dispersas e precisava dar logo forma a eles e botar no papel. E queria começar justamente por ela, Dona Navalha, nome que, apesar de martelar e martelar em minha cabeça há seis meses, ainda não tinha me percebido do óbvio: Dona Navalha para além de pronome de tratamento seguido de nome próprio diz algo bem mais simples, que ela é a dona da navalha.

Meu primeiro dia de carnaval foi, portanto, escrevendo a partir dessa ideia. Com a vela acesa aos seus pés, sua taça cheia, me punha a escrever sobre os segredos dessa que, apenas ela, guarda todos os segredos de um pensamento que se constrói $a$ 
navalhadas. Navalha iniciou a série de escritas para o livro, foi quem me deu o caminho para a escrita arruaceira e, a cada dia, a cada texto que começava a trabalhar sobre, sua vela era acesa junto a de alguém que ela trazia para a escrita, me ajudando a não mais cunhar os conceitos, pois o processo de conceitualização é absolutamente outro do que o da cunhagem tradicional, sendo mais próximo a um navalhamento dos conceitos, cujo resultado são desconceitos.

Pois sim. Se Nietzsche defendia a filosofia a golpes de martelo, que pretende destruir tudo que se quer solidificar; se Derrida disse que Nietzsche pensa com as esporas, que dão o ritmo dos galopes; se Preciado disse que Derrida era o filósofo das tesouras, que recortam, mudam de lugar, deslocam os poderes e muito mais - podemos dizer então, graças à sua dona, que uma filosofia popular brasileira precisa ser escrita a golpes de navalha.

Sendo de posse da mulher, a navalha pode ainda mais do que poderia se apenas coubesse ao malandro. A mulher navalhadora é, também, é certo, a que carrega a arma por debaixo de suas vestimentas - é bom lembrar que Maria Navalha pode usar tanto saia quanto calça. Em suas mãos, a navalha é tanto a arma da luta que só é acionada em última instância (pois a malandragem ensina a recuar o máximo que puder, deixar que o inimigo venha pra cima de você, e nunca partir direto ao ataque), mas também é a operadora do renascimento e feitora das curas que se escondem por detrás do efun, do waji e do ossun.

Nos dois casos, vertedora do ejé, a navalha, para além do bem e do mal e para aquém de vida e morte, marca a pele, deixa suas cicatrizes e mostra que o pensamento tem que ser uma coisa de pele ${ }^{13}$. Esta arma encantadora, entregue ao malandro pela mulher, como que o tornando Cavaleiro pelas mãos da Rainha da Lapa, seu valete das encruzas, deve ser a mesma que ela, a Dona, nos lega ao batizar nossas canetas e ao transformar nossas mãos um feixe de navalhas que, ao tocar as teclas do computador, desconceitua, descaceta, despiroca tudo.

Assim, dia após dia, depois de finalizado o texto inaugural escrito em homenagem àquela que parece ser madrinha dessas novas escritas que se me impõem ${ }^{14}$, eu ia navalhando os outros rabiscos que tinha, à navalha de Dona Maria se somava à de outro João, o da Gomeia, somavam-se índios, polacas, pretos velhos, exus e

\footnotetext{
${ }^{13}$ Citação do recente e fundamental texto de Marcelo José Derzi Moraes "Por uma Filosofia dessa coisa de pele: uma desconstrução da colonialidade" (NOYAMA, 2020).

${ }^{14}$ Trata-se de "Filosofia a golpes de navalha", (SIMAS, RUFINO e HADDOCK-LOBO, 2020, 25-29).
} 
pombagiras, boiadeiros, filósofos e filósofas daqui e de lá, enquanto o samba corria solto do lado de fora e do de dentro de minha casa e invadia a escrita. Porque não é isso, também, o que exige a navalha: que a rua invada o texto, que o corpo se ponha à disposição da rua, que a rua encante a filosofia?

\title{
フフフフフォ
}

\section{Sexto golpe: navalha quebrada}

\begin{abstract}
Maria Navalha disse cuidado pra não errar ela jurou, jurou, tornou jurar

Que mata sem tirar sangue, engole sem mastigar.

(Ponto de Maria Navalha)
\end{abstract}

Findado o livro, enviado à editora, parecia que as Arruaças com os compadres Simas e Rufino tinham encerrado minha "obrigação" com Dona Navalha. Mas, é claro, que quando se trata de exus e pombagiras, as coisas nunca se dão como e quando queremos, eles sacaneiam qualquer anseio a subjetividade: não há subjetivação possível nas e das ruas, se sujeito for entendido como quer o ocidente - racional, livre, autodeterminado; se há algum processo de (des)identidade que a rua ensina é a exubjetivação.

Nossa exubjetividade nada mais é que seguir o que acontece e estar disponível ao acontecimento ${ }^{15}$. Não precedemos a nada, não existimos enquanto nós mesmos, como seres presentes a si, autônomos e o caralho a quatro, a gente vem depois. O que a gente chama de "eu" nada mais é que a chegada em uma gira que já começaram há muito tempo!

Mas isso tudo pra mostrar que se alguém estiver fechado em seus objetivos, ou achar que já chegou a algum lugar, não vai sair de onde estava, vai ficar achando apenas o que já sabia que ia achar. A ginga que a escrita tem que seguir é também estar de com um olho no gato e outro no peixe e preparado para as quizumbas que vão aparecer. Até

\footnotetext{
${ }^{15}$ Revendo o vídeo do lançamento do Arruaças, observo a importância, em diversos momentos, da ideia de disponibilidade (https://www.eventials.com/labpub/lancamento-do-livro-arruacas-uma-filosofiapopular-

brasileira/?utm campaign=reminder\&utm medium=email\&utm source=email\&fbclid=IwAR3NKnseue DaFgBQI6SrNHzDjcQ3a4tzzLJN 95CfqgHPbtezU6dR63CunU). Dispinibilidade é a palavra central para que aconteça a exubjetivação.
} 
porque, o que é a escrita navalhada, a que sangra e cura, senão uma resposta às quizumbas das nossas vidas?

Cumpadre Rufino, filósofo jongueiro e capoeira, o triângulo fininho e preciso que toca nossos xotes filosóficos ${ }^{16}$, me ensinou que pensar é estar preparado para o tombo. Achava eu, com minha ignorância aliada ao corpo branco e gordo que dificilmente consegue gingar, que otário era aquele que levava tombo. Rufino me ensinou que, mais cedo ou mais tarde, todo mundo cai, e o malandro é aquele que cai bonito, porque sabe que vai cair. O otário, ao contrário, é o que cai feio, porque não sabe cair e nem sabe que vai cair. Daí a lindeza filosófica das rasteiras, que é o golpe do corpo navalhado, do devir navalha do corpo malandro.

Tal como as cadeiras de arruar que nos lembra a apresentação do Arruaças $^{17}$, onde as sinhás se acham protegidas dos corpos fundangueiros, quizumbeiros e cafofentos. Essas, as sinhás em suas cadeiras, não preveem que esses corpos nas ruas vão leva-las ao "tombo na subida"18. "Subjetividade" é, portanto, outro desses conceitos em cadeiras de arruar, que se quer protegido da zorra que come nas ruas e que, depois de navalhado, se exuzilha ${ }^{19}$. É nesse sentido que o desconceito é o tombo que os conceitos levam em seu caminho de subida e escorregam ladeira abaixo. E, notando aparentemente que os conceitos querem sempre subir, nos entristecemos ao saber que, para subirem, eles desceram, com a moral toda enterrada na lama, parafraseando Mauro Bolacha $^{20}$.

\footnotetext{
${ }^{16}$ Ainda no lançamento do livro, Simas, ao pensar nossa trinca, lembra do trio que acompanhava Luiz Gonzaga, cata milho, custo de vida e salário mínimo e, logo em seguida, afirmando que Luiz Rufino seria o triângulo, fininho e capoeirista, sobrando para nós dois sermos a zabumba e a sanfona.

17 "Nos tempos da escravidão, as cadeiras de arruar eram liteiras carregadas por escravizados em que as sinhás passeavam pelas ruas da cidade. Em geral, elas tinham portinholas que visavam proteger as sinhás dos perigos representados pelos desordeiros que incendiavam as ruas com suas fundangas, promoviam quizumbas nas encruzas e se entocavam em seus cafofos: os arruaceiros. Esse perigoso gentio, que começava a anunciar a tarefa dos brasis contra o Brasil, era versado em muitas invenções, matutações e feitiços, mestres em pembas e mandingas, doutores em queimações, trucos, mumunhas, desenfadados nas mugingas e nas canjiras. Praticavam, como modo de vida, a arruaça, incorporando o cruzo e alargando o tempo. Quando seu adversário tá fazendo um alarde danado, eles davam só aquela escorada, às vezes de leve, que desequilibra o oponente e que gera o maior esculacho. Porque arruaça é jogo na aldeia" (SIMAS, RUFINO e HADDOCK-LOBO, 2020, 11-12).

18 Título da apresentação do livro.

${ }^{19}$ Exuzilhar, verbo neologizado por Cidinha da Silva em 2010, na tentativa de navalhar ainda mais o verbo encruzilhar, aparece em diversas de suas obras e intitula seu recente livro (SILVA, 2018).

${ }^{20}$ Ainda consigo ouvir Simas cantarolando, quando pensamos em botar o samba como epígrafe do livro: "Pelo curto tempo que você sumiu / Nota-se aparentemente que você subiu / Mas o que eu soube a seu respeito / Me entristeceu, ouvi dizer / Que pra subir você desceu / Você desceu. / Todo mundo quer subir / A concepção da vida admite / Ainda mais quando a subida / Tem o céu como limite / Por isso não adianta estar / No mais alto degrau da fama / Com a moral toda enterrada na lama" (Lama, Mauro "Bolacha" Duarte).
} 
Pois bem, depois desse desvio todo, desses salamaleques da escrita filosófica, esse aforismo cumpre nesse texto o papel de contar que, um belo dia, a navalha quebrou. Um dos pinos que prende a lâmina soltou e nunca mais achei. O engraçado é que a navalha capenga antecipou a tomada de algumas decisões quanto à escrita final do Arruaças, depois de revisões e revisões. Uma frase minha, justo a que fechava o texto dedicado à navalha, estava destoando completamente da escrita do livro. Ao invés de alterá-la, mudando alguns desconceitos que ali apareciam, preferi retirar a sentença inteira. De início, não posso negar que tive um intenso conflito interno, mas, como Simas me ensinou lá atrás, lembrando das ensinanças do Bar Madrid de meses atrás, decidi vestir os sapatos no texto pra que a Navalha andasse descalça.

Porém, a navalha quebrada, em cima da minha mesa do escritório, que parecia se recusar a ser despachada, parecia querer dizer que ainda tinha muito coro para comer.

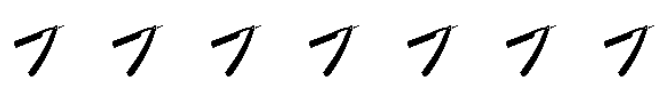

\section{Sétimo golpe: Navalhar os conceitos}

Ela é malandra não precisa trabalhar Maria Navalha bota tudo em seu lugar. (Ponto de Maria Navalha)

Esse texto ganha sua forma final depois do lançamento de Arruaças, ou seja, quando a filosofia a golpes de navalha já foi arriada cuidadosamente nas ruas. Talvez, nesse sentido, esse texto seja uma longa nota de rodapé ao pequeno e cuidadoso texto que escrevi para o livro em parceria com os pensadores que tanto admiro. Talvez aqui tenha mais coisa, ou talvez menos, pois ali a navalhada é certeira, curta e grossa, indo na cara daqueles que esperavam de mim qualquer escrita conceitual ou acadêmica.

Mas, então, o que me motiva a escrever estas páginas que não se encontra ali? Em outros termos: o que a navalha ainda pode querer de mim?

Falo aqui da importância do lançamento do Arruaças - de modo algum para uma autopromoção - pois houve algo naquele momento que me pareceu fundamental para dar caminho a essa escrita: a forma. Como Simas explicou no lançamento do livro ${ }^{21}$ o livro é composto de um carteado de textos, no qual em cada capítulo um dá a primeira

\footnotetext{
${ }^{21}$ Ver link supracitado.
} 
carta e fecha a gira: assim, "Fundanga" abre com Simas, seguido por Rufino e por mim, "Quizumba" é Rufino quem abre, seguido por mim e por Simas, e eu abro "Cafofo", seguido por Simas e Rufino. O bacana do lançamento é que a essa gira se somou a voz de Moyseis Marques, trazendo a lama, o ritmo, e completando a sacanagem.

Sim, sacanagem. A fala de abertura de Simas compara o livro ao petisco de bar em que cada um ia trepando uma coisinha sobre a outra, a salsicha, o queijo, a cenoura... Porém, essa fala do Simas, ela quebra a expectativa de seriedade, de linguagem erudita, de qualquer intelectualismo. E ela deu o tom. Daí em diante, era só cada um assumir sua parte na sacanagem geral que é o livro.

Essa epistemologia da sacanagem é coisa séria demais. É papo de boteco, muito mais potente do que a forma dialógica da filosofia, pois se assemelha muito mais à abertura ao improviso do partideiro, é um jogo de bola que sempre nos pega de surpresa e nos obriga a inventar. Ele ensina que a ginga do pensamento está em frustrar qualquer expectativa que se tenha, sem se deixar prender em nenhuma cela epistemológica, como bem nos ensinaram Pelintra, Satã e Navalha: quando a rádio patrulha (que na maioria das vezes pode ser o discurso acadêmico, o purismo religioso, o burburinho decolonial), é hora de dar no pé!

Mas ainda tem mais: quando Simas solta a sacanagem no ar, parece que dá para imaginar a boa e velha filosofia enrubescendo de vergonha de ouvir tal palavra de baixo calão; a senhora academia se retira do salão diante de tal linguajar impróprio e os cidadãos de bem piram. Pois é isso que um desconceito como a sacanagem opera na boca de Simas: ele navalha o coração da arquitetura e da moralidade do pensamento erudito. Me lembrou um professor, o falecido Clauze Ronald de Abreu, no primeiro período da graduação em filosofia: ele entra na sala cheio de meninos burgueses e pseudo-padrecos (a filosofia da UFRJ na década de noventa era isso, e eu estava entre os meninos burgueses), em sua aula de Psicologia 1, diz que em psicanálise se trata de desejo. Então, ali não se falará de pênis, vagina nem anus, pois esses conceitos pertencem à biologia, mas sim de caralho, buceta e cu. Imagina a situação da turma.

Mas que, como eu, fui educado na pedagogia de Seu Tranca Rua das Almas, que quando baixava a primeira palavra que seguia sua gargalhada era "puta que pariu", entendi no momento que quando se trata das ruas (parafraseando aqui a palavra desejo, que ainda acho carregada demais de eruditismo) tem coisa que só se expressa no palavrão. "Hahaha, puta que pariu, boa noite, moxo!" dizia, para além do expresso na significação das palavras, a felicidade do encontro. Que bom estar entre vocês, que bom 
estar aqui para beber minha cachaça, fumar meu charuto, dar minhas risadas e encabular quem não gosta de palavrão.

Alias, Seu Tranca Rua de meu pai merece um dia uma escrita só para ele, de tanta sabedoria que me transmitiu, sempre regada de muito palavrão e muita sacanagem.

Mas o que Clauze, Tranca Rua e Simas fizeram foi me fazer retomar essas anotações para pensar em uma possível conclusão a esse texto que nada mais é que um relatório de campo de minhas experiências com Navalha e a malandragem. E o que a navalha quebrada parece me pedir, para enfiar o pino que nunca encontrei no buraco vazio, é a elaboração desconceitual de dois termos: embucetamento e descaralhamento.

Se Derrida, o magrebino velho, nos dizia que a desconstrução tem um duplo movimento, que se complementam e se dão em um mesmo golpe (de navalha), a inversão e o deslocamento ${ }^{22}$, podemos pensar que, da mesma maneira, embucetamento e descaralhamento são movimentos complementares e só funcionam juntos na navalhação.

Se despirocar é o ato de emascular a razão colonial e descacetar é tirar o cacete ou baixar o cacete nos puliças dos saberes, descaralhar é tocar o maior zaralho e bagunçar todo o coreto das caretices, dos calhordas, dos quiumbas do saber. Não há maior potência de desconstrução do falocentrismo do que o descaralhamento.

Mas, para além das pirocas, dos cacetes e dos caralhos, que são destronados nessa inversão do patriarcado colonial, em que a ereção cai e o sujeito branco ocidental parece ficar frustrado com sua impotência, a frustração do sujeito broxa abre espaço para a entrada de algo que só a mulher pode trazer para a cena do pensamento: o embucetamento.

Se o padilhamento ${ }^{23}$, como nos mostram Simas e Rufino, é o imperativo pindárico das macumbas, "o venha a ser a pomba-gira que tu és", em que os corpos ganham a leveza e giram e as saias se tornam as bocas de Enugbarijo ${ }^{24}$, quando essas saias entram na gira com as navalhas escondidas sob suas sete camadas, mais do que descaralhar, elas embucetam ${ }^{25}$.

\footnotetext{
22 Ver nota 4.

${ }^{23}$ Ver nota 6.

${ }^{24}$ Sobre isso, remeto ao importantíssimo capítulo "Tudo que a boca come: incorporações e mandingas", de Pedagogia das encruzilhadas de Luiz Rufino, onde lemos: "O domínio de Exu intitulado como Enugbarijó, o senhor da boca coletiva, nos diz sobre (...) todas as dinâmicas de transformação, reprodução, multiplicação, possibilidade, imprevisibilidade, criação, comunicação, mediação e tradução" (RUFINO, 2019, 141).

2525 Uma linda demonstração desse embucetamento filosófico é o capítulo final do livro Querendo ou podendo ser Lilith: a mulher um ser-outro, de Georgia Amitrano. Sua competente pesquisa sobre a
} 
Embucetar, que não é embocetar pois não tem nada a ver com guardar em uma caixa, pelo contrário, pois o descaralhamento já arrancou fora todos os arcontes das caixas e os guardas dos armários, é desconceito que aprendi desde cedo com minha mãe e que sempre denotou em sua boca a pressa, a correria, mas com certa raiva ou violência. "Aquele carro passou embucetado", dizia ela. Tinha pressa, certamente, mas uma pressa perigosa e que podia dar merda pra todo lado.

Contudo, tem algo que me parece ainda mais forte no embucetamento. Mais pelíntrico do que o empoderamento, no qual o cajado, a bengala ou o ogó ainda parecem ostentados, o embucetamento que se segue ao padilhamento recusa a ostentação fálica. Seu poder, se é que esse termo ainda serve, já que o embucetamento é a desconceitualização do poder, consiste justamente em esconder a arma em baixo da saia. A malandragem nos abre a uma outra relação do poder, uma certa recusa, uma certa passividade, contanto que a arma esteja lá, porque malandro não é otário.

E esse impoder, esse "prefiro não" como diria o malandro Bartleby, ao contrário do que se pode pensar, não tem nada de fraco. A saia que roda é a saia que engole sem mastigar, pois não precisa de dentes. Ela engole e cospe tal como o masculino, mas em uma espécie de dança, de coreografia hipnótica em que o inimigo nem sabe que é engolido. Embucetado, a pergunta de Espinoza "o que pode um corpo" parece nem mais fazer sentido ${ }^{26}$, pois não se trata de poder, se trata de engolir, de cuspir e de criar novas danças.

Sim. Talvez seja desse duplo movimento, desses dois golpes com uma só navalha, que essa moça, minha madrinha sem ela nem mesmo saber, quisesse que eu escrevesse para completar esse percurso que se segue há mais de um ano. Navalhar a filosofia, escrever uma filosofia a golpes de navalha, desconceituar o que se pretende ereto, é, ao mesmo tempo, navalhar as teorias do conhecimento, navalhar os gêneros, navalhar os poderes. Com um só golpe.

\footnotetext{
ontologia do feminino ao longo da história do ocidente, sobretudo nas mitologias gregas e judaicas, ganha uma potência ainda maior quando as figuras femininas embocetadas de brasilidade chegam e dão um outro tom ao livro. Explica a autora: "Minha Lilith, ainda que esteja na base da Zohar e nos preceitos judaicos que se mantêm no discurso dos 'cristãos', ultrapassa esse encosto europeu, excedendo o espectro enorme e pesado que carrego. Minha Lilith roda, gira, faz as saias balançarem, anda pelos becos, bebe e fuma, pode ser loura ou morena, polaca ou negra. Minha Lilith é o que sou, brasileira, miscigenada das culturas, das etnias, uma ovelha Outra da família, uma Lilith que também pode e deve ser Pomba-gira. Trazer essa minha Lilith aqui, todavia, implica dizer das Áfricas e das Europas, falar dos imaginários da mulher africana e indígena, latino-americana e dos mitos que trouxeram para nós. A mitologia aqui se mistura no ato miscigenado e autêntico de uma brasilidade. E é essa Lilith que eu pretendo aqui apresentar, distorcer, profanar e, por fim, fazê-la numa gira pomba-lilithiar" (AMITRANO, 2020, 126).

${ }^{26}$ Ver nota 11.
} 
É assim que essa malandra que não precisa trabalhar faz, Maria navalha bota tudo em seu lugar, tirando tudo de seu lugar que é previamente dado, fazendo todos recuarem com sua navalha afiada.

E isso só é possível porque Maria Navalha chega embucetada para descaralhar a porra toda.

\section{Referências bibliográficas}

AMITRANO, Georgia. Querendo ou Podendo ser Lilith: a mulher um ser-outro. Rio de Janeiro: Ape'ku, 2020.

BORGES-ROSÁRIO, Fábio; MORAES, Marcelo José Derzi; HADDOCK-LOBO, Rafael. Encruzilhadas Filosóficas. Rio de Janeiro: Ape'Ku, 2020.

DERRIDA, Jacques. Posições. Belo Horizonte: Autêntica, 2001.

HADDOCK-LOBO, Rafael. Filosofia Popular Brasileira. HH Magazine, Humanidades em Rede: https://hhmagazine.com.br/category/colunas/filosofia-popular-brasileira/

HADDOCK-LOBO, Rafael. Os Fantasmas da Colônia: notas de desconstrução e filosofia popular brasileira. Rio de Janeiro: Ape'Ku, 2020.

MORAES, Marcelo José Derzi e NEGRIS, Adriano. "Escrituras da Cidade: ordem e desordem a partir de Derrida". In: SOLIS, Dirce Eleonora Nigro e MORAES, Marcelo José Derzi. Políticas do Lugar (Coleção Querências de Derrida, moradas da arquitetura e filosofia, vol. 4). Porto Alegre: UFRGS, 2016.

MORAES, Marcelo José Derzi. "Por uma Filosofia Dessa Coisa de Pele: uma desconstrução da colonialidade". In: N NOYAMA, Samon. Gingar, Filosofar, Resistir: ensaios para transver o mundo. Curitiba: CRV, 2020.

RIO, Joao do. A Alma Encantadora das Ruas. Rio de Janeiro: Nova Fronteira, 2012.

RUFINO, Luiz. Pedagogia das Encruzilhadas. Rio de Janeiro: Mórula, 2019.

SILVA, Cidinha da. Exuzilhar. São Paulo: Kuanza Produções, 2018.

SILVA, Wallace Lopes (org.). Sambo, Logo Penso: afroperspectivas filosóficas para pensar o samba. Rio de Janeiro: Hexis, 2015.

SIMAS, Luiz Antonio, RUFINO, Luiz e HADDOCK-LOBO, Rafael. Arruaças: uma filosofía popular brasileira. Rio de Janeiro: Bazar do Tempo, 2020.

SIMAS, Luiz Antonio e RUFINO, Luiz. Fogo no Mato: a ciência encantada das macumbas. Rio de Janeiro: Mórula, 2018. 
SIMAS, Luiz Antonio e RUFINO, Luiz. Flecha no Tempo. Rio de Janeiro: Mórula, 2019.

SIMAS, Luiz Antonio. O Corpo Encantado das Ruas. Rio de Janeiro: Civilização Brasileira, 2019.

SIMAS, Luiz Antonio. Pedrinhas Miudinhas: ensaios sobre ruas, aldeias e terreiros. Rio de Janeiro: Mórula, 2019.

VIDARTE, Paco. Ética Bixa: proclamações libertárias para uma militância lgbtq. São Paulo: n-1, 2019).

Recebido em: 01/10/2020

Aceito em: 16/12/2020 